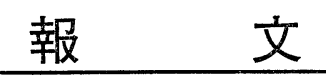

色材, 66 (11), 643-648 (1993)

\title{
ピリドキサール修飾 $\gamma$-リン酸ジルコニウムの合成と応用
}

郭 玉剛*・藤井孝宜*・伊藤征司郎*・吉原正邦*・前嶋俊壽*

\section{要旨}

rーリン酸ジルコニウム $(\mathrm{ZrP})$ とピリドキサールー5'ーリン酸 $(\mathrm{PL})$ ならびに鎖長の異なる有機りン酸とを加熱 還流下反応させた。生成粉体は, ZrP の層間に PLならびに有機りン酸が同時にインタカレーションした化合物 であり，有機リン酸の有機鎖が長いものほど層間距離が長くなることが判明した。

つぎに, これら修飾粉体を用いて，フェニルアラニンとピルビン酸とのアミノ基転移反応に対する触媒活性に ついて検討した。その結果, 金属イオンとして $\mathrm{Cu}^{2+}$ を共存させると高い触媒活性が現れた。また, アミノ基転 移反応は，有機りン酸の有機鎖長に関係があり $n-\mathrm{C}_{12} \mathrm{H}_{25} \mathrm{OPO}_{3} \mathrm{H}_{2}$ て修飾した粉体を用いると, PL 含有量を基に して 554\%のアミノ酸が生成していることが判明した。

\section{1. 諸言}

$\gamma$ ーリン酸ジルコニウム $\mathrm{Zr}\left(\mathrm{HPO}_{4}\right)_{2} \cdot 2 \mathrm{H}_{2} \mathrm{O}$ (以下 $\mathrm{ZrP}$ と略）は，ジルコニウム原子上の上下にリン酸基が結合 した結晶性無機層状化合物である ${ }^{11}$ 。リン酸基上のプロ トンは種々の陽イオンと交換が可能であり, またジルニ ニウムと結合しているリン酸基も他のリン酸エステルと の交換が可能である゙2。このことから， ZrP は無機イオ ンまたは他のゲスト化学種との間にインタカレーション 化合物を形成することが知られていて，主に無機材料へ の用途に関する研究が行われている゙๋。しかし，ZrPを 有機化学分野へ応用した例は見られない。

本論文では，ビタミン $\mathrm{B}_{6}$ 補酵素であるピリドキサー ル-5'ーリン酸 (以下 PL と略) と ZrP ならびに有機り ン酸とのリン酸エステル交換により, 層間に PLならび に鎖長の異なる有機基を同時にインタカレーションした 修飾粉体を合成し，酵素反応で見られる $\alpha$-アミノ酸と $\alpha$ ーケト酸とのアミノ基䎐移反応 ${ }^{4)}$ に対する触媒活性につ いて検討した。

\section{2. 実 験 方 法}

\section{1 試 薬}

ZrP は第一希元素化学工業株式会社製 CZP-200（純 度 $98 \%$ ）を用い，そのほかの溶媒あるいは試薬は常法に

平成 5.6.17 受理

* 近畿大学理工学部応用化学科

東大阪市小若江 3-4-1 (宁577)
より精製したものを用いた。

\section{2 分 析}

IR スペクトルは PERKIN-ELMER FT-IR 1760-X 型を使用し，KBr 錠剤法あるいは拡散反射法により測 定した。

粉末 X線解析装置は理化学電気 (株) 製のガイガーフ

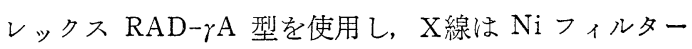
による CuX $\alpha$ を用い, 電圧 $40 \mathrm{kV}$, 電流 $80 \mathrm{~mA}$ で測定 した。

液体クロマトグラフは島津製送液ニニット LC-6 A おo よび紫外分光光度計検出器 SPD-6A を使用し, カラム は綜研化学 (株) 製 ODS-ST $(25 \mathrm{~cm} \times 0.46 \mathrm{~cm}$ i.d. $)$, 移動相はトリス $/ \mathrm{HCl}$ 緩衝溶液 $(\mathrm{pH} 8.1)$ ：メタノール 混合溶媒を用いた。

\section{$2.3 \mathrm{ZrPL}$ の合成}

各修飾粉体は Scheme 1 に従って合成した。PL 塩酸 塩 $20 \mathrm{~g}$ (75 mmol) を水 $150 \mathrm{ml}$ に溶解し, $Z \mathrm{rP} 5 \mathrm{~g}$ を 加えて 24 時間還流擋拌した。その後, 濾別し, 濾液に PL が認められなくなるまで蒸留水およびメタノールに よって粉体を洗浄した。合成粉体 ZrPL は真空デシケー ター中で乾燥した。

\section{4 有機リン酸修飾 $\mathrm{ZrPL}$ の合成}

$\mathrm{PL}$ 塩酸塩 $20 \mathrm{~g}(75 \mathrm{mmol})$ と有機リン酸エステル $\mathrm{ROPO}_{3} \mathrm{H}_{2} 75 \mathrm{mmol}$ を水/アセトン $=1 / 1$ 混合溶液 150 $\mathrm{m} l$ に溶解し, そこに $\mathrm{rP} 5 \mathrm{~g}$ を加兄 24 時間還流擋拌 した。その後, 濾別し, 粉体をアセトン, メタノールで 十分洗浄した。各修飾 $\mathrm{ZrPL}$ をそれぞれ $\mathrm{ZrPL}-\mathrm{C}_{3}(\mathrm{R}=$ 

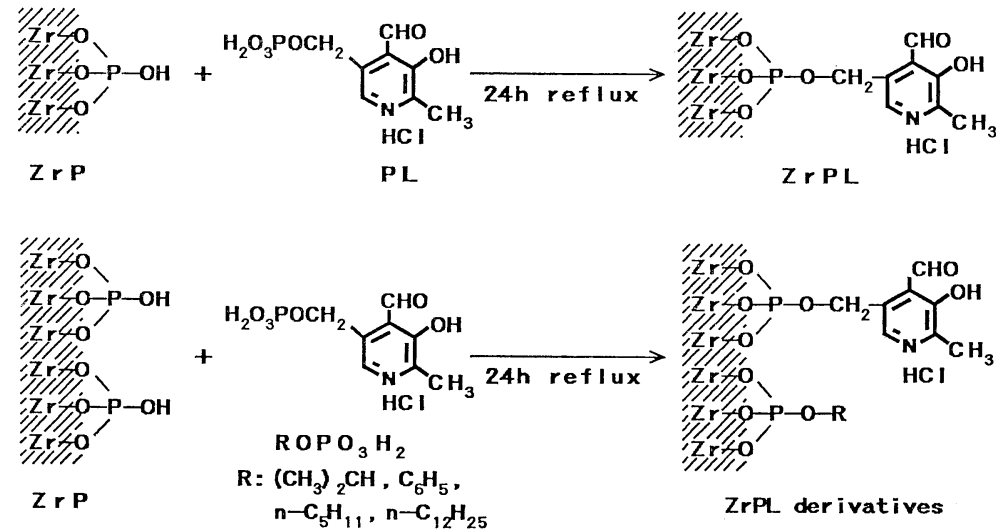

Scheme 1 Preparation of $\mathrm{ZrPL}$ and its derivatives.

$\left.\mathrm{Me}_{2} \mathrm{CH}\right), \quad \mathrm{ZrPL}-\mathrm{Ph} \quad\left(\mathrm{R}=\mathrm{C}_{6} \mathrm{H}_{5}\right), \quad \mathrm{ZrPL}-\mathrm{C}_{5} \quad(\mathrm{R}=n-$ $\left.\mathrm{C}_{5} \mathrm{H}_{11}\right), Z \mathrm{ZrPL}-\mathrm{C}_{12}\left(\mathrm{R}=n-\mathrm{C}_{12} \mathrm{H}_{25}\right)$ と略記する。また, $\mathrm{ZrPL}-\mathrm{C}_{12}$ については, $\mathrm{ZrP} 5 \mathrm{~g}$ および $n-\mathrm{C}_{12} \mathrm{H}_{25} \mathrm{OPO}_{3} \mathrm{H}_{2}$ $75 \mathrm{mmol}$ に対し添加 PL 量を変化させて, 上記と同様に 反応させ, $\mathrm{PL}$ 含有量の異なる修飾粉体（それぞれ $\mathrm{ZrPL} \mathrm{C}_{12}$ (1) ZrPL-C $\mathrm{C}_{12}$ (6) と略記) を合成した。

\section{5 アミノ基転移反応}

$\alpha$-アミノ酸 $(0.22 \mathrm{mmol})$ と $\alpha-$ ケ酸 $(0.22 \mathrm{mmol})$ を酶酸/酢酸ソーダ緩衝溶液 ( pH 5.0) $50 \mathrm{ml}$ に溶解し, 修飾粉体 $25 \mathrm{mg}$ を加光, 30 分間予備擋拌した。その後, 過塩素酸銅 $0.14 \mathrm{mmol}$ を加光, 擋拌下 $30^{\circ} \mathrm{C}$ で反応させ た。反応経過は，アミノ基転移反応によって生成または 減少するアミノ酸を HPLC によって追跡した。アミノ 酸の同定, 定量は, ダンシル化反応によって行っだ)。 すなわち, $\mathrm{pH} 9.3$ のホウ酸ナトリウム $/ \mathrm{NaOH}$ 緩衝溶
液 $250 \mu l$ に反応混 合溶液 $50 \mu l$, 内部標準試薬 $50 \mu l$ $\left(4.4 \times 10^{-3} \mathrm{M}\right)$, EDTA $23 \mu l\left(22 \times 10^{-3} \mathrm{M}\right)$ ならびに, ダンシルクロリドのアセトニトリル溶液 $250 \mu l\left(5 \times 10^{-3}\right.$ M) を加え, 室温で約 1 時間暗所に放置した。その後, 2.2 に述べた方法に従い，液体クロマトグラフを用いて 分析した。反応率（\%）は各修飾粉体に含有されている PL 触媒基量を基にして計算した。

\section{3. 結果および考察}

\section{1 修飾粉体のキャラクタリゼーション}

各粉体の粉末 $\mathrm{X}$ 線解析, 元素分析值および PL 含有量 の測定結果を表-1に示した。粉末X線解析の結果, $\mathrm{ZrPL}$ (No.2) の層間距離 $15.6 \AA$ は元の $\mathrm{ZrP}$ (No.1) の層間距離 $12.2 \AA$ よりも大きくなっている。さらに, 有機リン酸基で修飾した合成粉体 (No.3〜7) の層間距

Table 1. X-Ray diffraction and elemental analysis of $\mathrm{ZrPL}$ and its derivatives

\begin{tabular}{|c|c|c|c|c|c|c|c|c|}
\hline \multirow{2}{*}{ No. } & \multirow{2}{*}{ Sample } & \multirow{2}{*}{$\frac{\text { Added PL }}{(\mathrm{mmol})^{\mathrm{a})}}$} & \multirow{2}{*}{$\frac{\mathrm{X}-\text { Ray }}{\text { basal space }(\AA)}$} & \multicolumn{4}{|c|}{ Elemental analysis } & \multirow{2}{*}{$\frac{\text { PL content }}{(\mathrm{mmol} / \mathrm{g})}$} \\
\hline & & & & $\mathrm{H}(\%)$ & $\mathrm{C}(\%)$ & $\mathrm{N}(\%)$ & $\mathrm{N} / \mathrm{C}$ & \\
\hline 1 & $\mathrm{ZrP}$ & 0 & 12.2 & - & - & - & - & - \\
\hline 2 & $\mathrm{ZrPL}$ & 75 & 15.6 & 1.88 & 6.5 & 0.87 & 0.135 & 0.62 \\
\hline 3 & $\mathrm{ZrPL}-\mathrm{C}_{3}$ & 75 & 17.8 & 2.28 & 10. 2 & 0.83 & 0.081 & 0.62 \\
\hline 4 & $\mathrm{ZrPL}-\mathrm{Ph}$ & 75 & 19.4 & 1.98 & 13.5 & 0.82 & 0.061 & 0.59 \\
\hline 5 & $\mathrm{ZrPL}-\mathrm{C}_{5}$ & 75 & 20.7 & 3.13 & 17.9 & 0.75 & 0.042 & 0.53 \\
\hline 6 & $\mathrm{ZrPL}-\mathrm{C}_{12}(1)$ & 150 & 26.2 & 2.98 & 16.6 & 0.73 & 0.044 & 0.52 \\
\hline 7 & $\mathrm{ZrPL}-\mathrm{C}_{12}(2)$ & 75 & 27.8 & 2.83 & 16.0 & 0.73 & 0.046 & 0.52 \\
\hline 8 & $\mathrm{ZrPL}-\mathrm{C}_{12}(3)$ & 37.5 & 29.9 & 3.47 & 18.2 & 0.69 & 0.038 & 0.49 \\
\hline 9 & $\mathrm{ZrPL}-\mathrm{C}_{12}(4)$ & 13.8 & 28.8 & 3.87 & 22.1 & 0.60 & 0.027 & 0.43 \\
\hline 10 & $\mathrm{ZrPL}-\mathrm{C}_{12}(5)$ & 9.4 & 30.5 & 4.43 & 25.8 & 0.57 & 0.022 & 0.40 \\
\hline 11 & $\mathrm{ZrPL}-\mathrm{C}_{12}(6)$ & 2.4 & 28.8 & 5.11 & 29.7 & 0.20 & 0.007 & 0.14 \\
\hline
\end{tabular}

a) $5 \mathrm{~g}$ of $\mathrm{ZrP}$ and $75 \mathrm{mmol}$ of $\mathrm{ROPO}_{3} \mathrm{H}_{2}$ were used. 
離は，有機基の長さに比例して順次桩大していることが 分かる。明らかに, PL ならびに有機リン酸基が層間に インタカレーションしていることを示している。また， $\mathrm{ZrPL}$ (No.2) のチッ素含有率と炭素含有率の比 N/C が 計算值 (0.130) とほぼ一致していることから, PL は分 解せずに $\mathrm{ZrP}$ 上に修飾されているものと考えられる。 さらに，有機リン酸基を修飾した粉体（No.3〜7）に掠 いては， N/C の值 0.081〜0.046 は ZrPL (No.2)の 值 0.135 に比べて小さくなっていて, PL と有機りン酸 基が $\mathrm{ZrP}$ 上に同時に結合していることを示している。ま た, $n-\mathrm{C}_{12} \mathrm{H}_{25} \mathrm{OPO}_{3} \mathrm{H}_{2}$ の場合, 有機リン酸化合物に対す る $\mathrm{PL}$ の添加量を減少させた時 (No.6〜No.11)，N/C 值は順次減少し, 同時に粉体中の PL 含有量も減少し た。

つぎに, $\mathrm{ZrP}$ と修飾 $\mathrm{ZrPL}$ 誘導体の $\mathrm{FT}-\mathrm{IR}$ スペクト ルを図-1 に示した。ZrPL には, 1680, 1553〜1386 cm-1 にPL に基づく吸収が確認された。また，ZrPL-Phe に ついても，PL に基づく吸収以外に，2922，2850，1470 $\mathrm{cm}^{-1}$ に $-\mathrm{CH}_{2}-$ に基づく吸収, さらに, $1490 \mathrm{~cm}^{-1}$ にフ ェニル基に基づく吸収が認められた。さらに, $3350 \mathrm{~cm}^{-1}$ の $\mathrm{ZrP}$ 表面水酸基に基づく吸収は，各修飾粉体におい て著しく減少していた。

以上の事実は，明らかに PL ならびに有機りン酸が $\mathrm{ZrP}$ 層間に修飾されていることを示している。

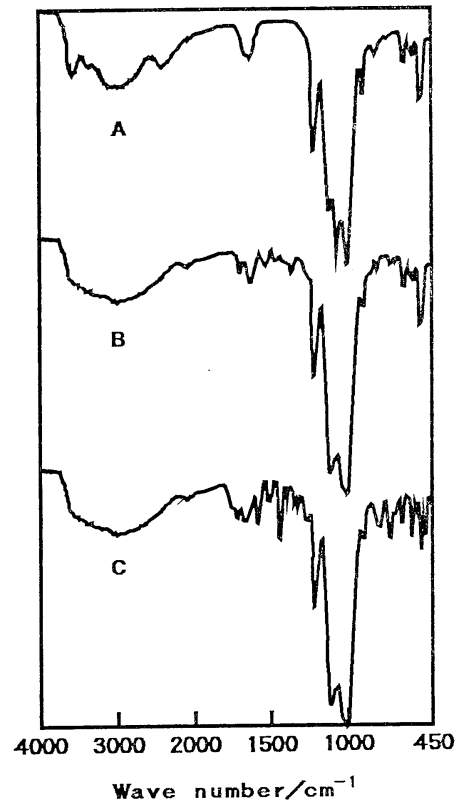

Fig. 1. IR spectra of (A) $\mathrm{ZrP}$, (B) $\mathrm{ZrPL}$, (C) $\mathrm{ZrPL}-\mathrm{Phe}$.
2.3 修飾粉体存在下フェニルアラニンとピルビン酸 とのアミノ基転移反応

図-2 の工程に従って,フェニルアラニン (Phe) とピ ルビン酸とのアミノ基転移反応について検討した。

図-3 に示したように, 反応時間と共に Phe が減少し (曲線 A)，一方アラニン（Ala）が生成している（直線 B)。な拈，反応初期に括いて，Phe の急激な減少が認

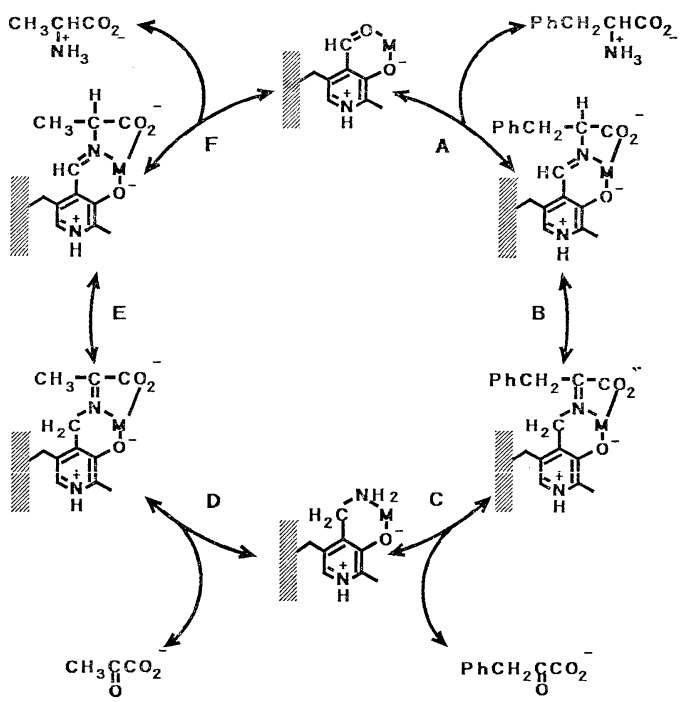

Fig. 2. Schematic representation of the transamination of phenylalanine and pyruvic acid with $\mathrm{ZrPl}$ and metal ions.

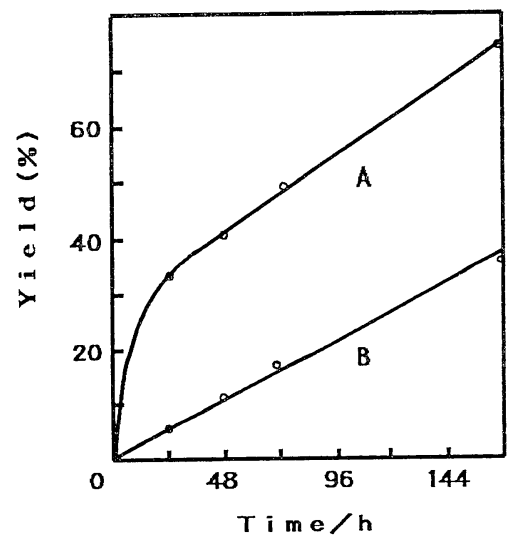

Fig. 3. Time course for the transamination of $\mathrm{D}, \mathrm{L}-\mathrm{Phe}$ with pyruvic acid catalyzed by $\mathrm{ZrPL}$ and $\mathrm{Cu}^{2+}$ in an aqueous acetate buffer ( $\mathrm{pH} \mathrm{5.0)}$ ) at $30^{\circ} \mathrm{C}$. D, L-Phe, $4.4 \times$ $10^{-3} \mathrm{mmol}$; pyruvic acid, $4.4 \times 10^{-3} \mathrm{mmol}$; $\mathrm{Cu}^{2+}, 2.8 \times 10^{-3} \mathrm{mmol} ; \mathrm{ZrPL}, 50 \mathrm{mg}$ (PL content $0.62 \mathrm{mmol} / \mathrm{g}$ ). A, Consumption of D, L-Phe ; B, Formation of Ala 
Table 2. The Effect of metal ions on transamination of DL-phenylalanine with pyruvate in the presence of $\mathrm{ZrPL}$ in an aqueous acetate buffer at $\mathrm{pH} 5.0$ and $30^{\circ} \mathrm{C}^{\mathrm{a}}$ )

\begin{tabular}{c|c}
\hline Metal ion & Relative reactivity ${ }^{\mathrm{b})}$ \\
\hline $\mathrm{Cu}^{2+}$ & 29.7 \\
$\mathrm{Ga}^{3+}$ & 14.9 \\
$\mathrm{Al}^{3+}$ & 3.0 \\
$\mathrm{Fe}^{2+}$ & 2.6 \\
$\mathrm{Fe}^{3+}$ & 1.8 \\
$\mathrm{Zn}^{2+}$ & 1.2 \\
$\mathrm{Co}^{2+}$ & 1.2 \\
$\mathrm{Mg}^{2+}$ & 1.1 \\
$\mathrm{Ni}^{2+}$ & 1.1 \\
$\mathrm{Mn}{ }^{2+}$ & 1.1 \\
None & $1.0^{\mathrm{c})}$ \\
\hline
\end{tabular}

a) D, L-Phe, $4.4 \times 10^{-3} \mathrm{mmol}$; pyruvic acid, $4.4 \times$ $10^{-3} \mathrm{mmol}$; metal ions, $2.8 \times 10^{-3} \mathrm{mmol} ; \mathrm{ZrPL}$, $0.025 \mathrm{mg}$ ( $\mathrm{PL}$ content $0.62 \mathrm{mmol} / \mathrm{g}$ ); reaction time, 7 days.

b) Analyzed by HPLC for Ala and calculated on the basis of initial reaction rates.

c) Initial rate $0.63 \times 10^{-5} \mathrm{mmol} / \mathrm{cm}^{3} \mathrm{~h}$.

められる。これは, 粉体表面の PL と Phe 間のトラン スフォーメーション（ $\operatorname{step} \mathrm{A} \rightarrow \mathrm{B} \rightarrow \mathrm{C}$ ) が反応初期に捈い て含まれているためと考えられる。

つぎに，アミノ基転移反応に及ぼす金属イオンの影響 について検討し，その結果を表-2 に示した。その結果， $\mathrm{Cu}^{2+}$ が最も高い反応性を示すことが判明した。そこで 以下の実験ではすべて $\mathrm{Cu}^{2+}$ を用いて行った。

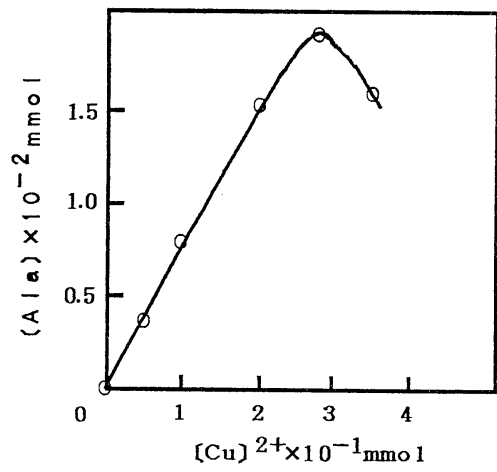

Fig.4. Effect of the concentration of $\mathrm{Cu}^{2+}$ on the yield of Ala in the reaction of Phe and pyruvic acid.

Ala 生成量に対する PL および $\mathrm{Cu}^{2+}$ 濃度の影響につ いて検討し，その結果を表-3 に示した。No.1〜 7 は PL 濃度を $0.031 \mathrm{mmol}$ として $\mathrm{Cu}^{2+}$ 濃度を変化させて行っ た結果であるが，その時の Ala 生成量と $\mathrm{Cu}^{2+}$ 濃度との 関係を図-4 に示した。 $\mathrm{Cu}^{2+}$ 濃度の増大につれて Ala 生 成量は増加し, $\left[\mathrm{Cu}^{2+}\right]=2.75$ 付近（その時の $\left[\mathrm{Cu}^{2+}\right]$ / $[\mathrm{PL}]=8.87)$ で Ala 生成量が最大值となっている。そ こで, $\left[\mathrm{Cu}^{2+}\right] /[\mathrm{PL}]=8.87$ として PL 濃度を変化させ たところ（表-3 の No. 6 拈よび No. 8～10), 図-5 に示 したように， $[\mathrm{PL}]=1.55$ 付近で Ala 生成量が一定とな った。以上のことから,この反応では, 適度な量の $\mathrm{Cu}^{2+}$ と PL が必要であることが判明した。

表-1 に示した各種 $\mathrm{ZrPL}$ 合成粉体を用いて, $\mathrm{Cu}^{2+}$ 存 在下 Phe とピルビン酸とのアミノ基転移反応を行い, その結果を図-6 に示した。いずれの合成粉体に持いて

Table 3. Transamination of DL-phenylalanine with pyruvic acid by $\mathrm{ZrPL}$ in an aqueous acetate buffer $(\mathrm{pH} 5.0)$ at $30^{\circ} \mathrm{C}$ )

\begin{tabular}{r|c|c|c|c|c|c}
\hline No. & $\begin{array}{c}\text { ZrPL } \\
(\mathrm{mg})\end{array}$ & $\begin{array}{c}\mathrm{PL} \text { content } \\
\left(\times 10^{-2} \mathrm{mmol}\right)\end{array}$ & $\begin{array}{c}\mathrm{Cu}^{2+} \\
\left(\times 10^{-1} \mathrm{mmol}\right)\end{array}$ & $\begin{array}{c}\mathrm{Cu}^{2+} \mathrm{PL} \\
\left.\left(\times 10^{-2} \mathrm{mmol}\right)(\%) \mathrm{b}\right)\end{array}$ \\
\hline 1 & 50 & 3.1 & 0 & 0 & 0.07 & 2.2 \\
2 & 50 & 3.1 & 0.55 & 1.77 & 0.33 & 10.8 \\
3 & 50 & 3.1 & 1.1 & 3.55 & 0.99 & 31.9 \\
4 & 50 & 3.1 & 1.65 & 5.32 & 1.25 & 40.3 \\
5 & 50 & 3.1 & 2.2 & 7.10 & 1.60 & 51.6 \\
6 & 50 & 3.1 & 2.75 & 8.87 & 1.79 & 57.9 \\
7 & 50 & 3.1 & 3.3 & 10.65 & 1.67 & 53.9 \\
8 & 100 & 6.2 & 5.5 & 8.87 & 1.61 & 26.0 \\
9 & 25 & 1.55 & 1.38 & 8.90 & 1.57 & 101.2 \\
10 & 10 & 0.62 & 0.55 & 8.87 & 0.61 & 98.2 \\
\hline
\end{tabular}

a) $[$ Phe $]=[$ pyruvic acid $]=4.4 \times 10^{-3} \mathrm{mmol}$, reaction time $=7$ days.

b) Based on PL content of the modified ZrPL. 


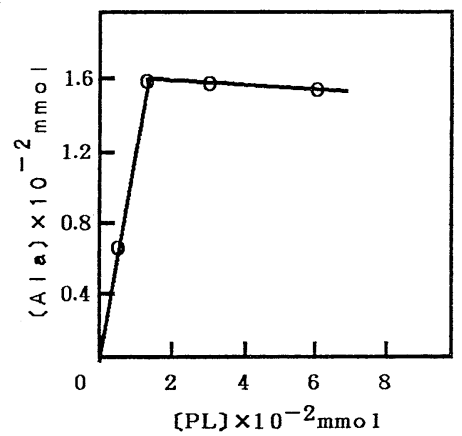

Fig. 5. Effect of the concentration of PL on the yield of Ala in the reaction of $\mathrm{D}, \mathrm{L}-$ Phe and pyruvic acid.

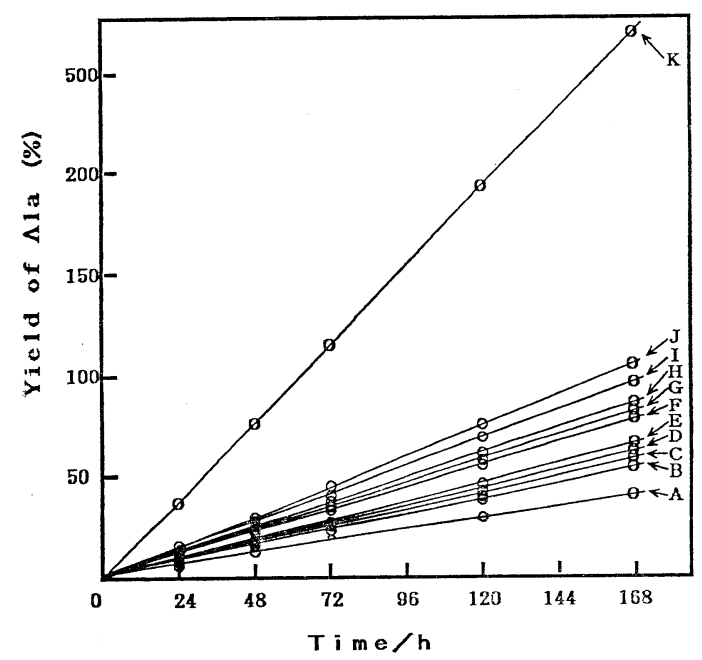

Fig. 6. Time course for the transamination of $\mathrm{D}, \mathrm{L}-\mathrm{Phe}$ with pyruvic acid in an aqueous acetate buffer (pH5.0) at $30^{\circ} \mathrm{C}$. Yield was evaluated on the basis of PL content in the modified powders. D, L-Phe, $4.4 \times$ $10^{-3} \mathrm{mmol}$; pyruvic acid, $4.4 \times 10^{-3} \mathrm{mmol}$; $\mathrm{Cu}^{2+}, 1.4 \times 10^{-3} \mathrm{mmol} ; \mathrm{ZrPL}$ derivatives, $25 \mathrm{mg}$. A, PL ; B, ZrPL ; C, ZrPL-Ph ; $\mathrm{D}, \quad Z \mathrm{rPL}-\mathrm{C}_{3} ; \mathrm{E}, \quad \mathrm{ZrPL}-\mathrm{C}_{5} ; \mathrm{F}, \quad \mathrm{ZrPL}-\mathrm{C}_{12}$ (1) ; G, ZrPL-C $\mathrm{Z}_{12}$ (2) ; $\mathrm{H}, \mathrm{ZrPL}_{\mathrm{rPC}} \mathrm{C}_{12}$ (3); I, $\mathrm{ZrPL}_{\mathrm{rP}} \mathrm{C}_{12}$ (4); J, ZrPL-C $\mathrm{Z}_{12}$ (5); K, $\mathrm{ZrPL}-\mathrm{C}_{12}$ (6)

も, PL の及の系 (A) に比べ反応性が増大している。 また，層間に有機基が導入されると反応性が一層増大 し，特に図中 $\mathrm{K} て ゙$ 示した $\mathrm{ZrPL}-\mathrm{C}_{12}$ （6）の系に拈いて は, $554 \%$ の Ala が生成していることが判明した。反応 率は修飾粉体中の $\mathrm{PL}$ 含有量を基に求めているので, Ala 生成量が 100\% を超えている事実は, PL 基が触媒 サイクルに入っていることを示している。図-7に,

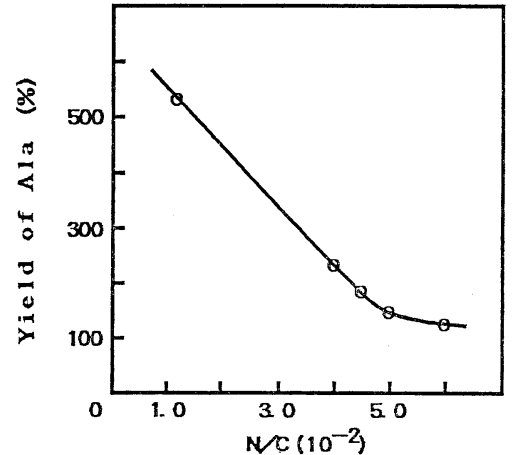

Fig. 7. Relationship between $\mathrm{N} / \mathrm{C}$ and the yield of Ala. D, L-Phe, $4.4 \times 10^{-3} \mathrm{mmol}$; pyruvic acid, $4.4 \times 10^{-3} \mathrm{mmol} ; \mathrm{Cu}^{2+}, 0.14$ $\times 10^{-3} \mathrm{mmol} ; \mathrm{ZrPL}_{\mathrm{r}} \mathrm{C}_{12}$ derivatives, $25 \mathrm{mg}$

Table 4. Transamination of $\alpha$-amino acid with $\alpha$-keto acid in the presence of $\mathrm{ZrPL}-\mathrm{C}_{12}$ (1) and $\mathrm{Cu}^{2+}$ in an aqueous acetate buffer $\left(\mathrm{pH} \mathrm{5.0)}\right.$ at $30^{\circ} \mathrm{C}$ )

\begin{tabular}{c|l|l|l}
\hline No. & $\begin{array}{c}\mathrm{R}^{1} \mathrm{CH}\left(\mathrm{NH}_{2}\right) \mathrm{CO}_{2} \mathrm{H} \\
1\end{array}$ & $\begin{array}{c}\mathrm{R}^{2} \mathrm{COCO}_{2} \mathrm{H} \\
\mathrm{R}^{2}\end{array}$ & $\begin{array}{l}\text { Relative } \\
\text { reactivity }\end{array}$ \\
\hline 2 & $\mathrm{CH}_{3}$ & $\mathrm{CH}_{3} \mathrm{CH}_{2}$ & 1.00 \\
3 & $\mathrm{CH}_{3}$ & $\mathrm{PhCH}_{2}$ & 1.64 \\
4 & $\mathrm{CH}_{3} \mathrm{CH}_{2}$ & $\mathrm{CH}_{3}$ & 1.00 \\
5 & $\mathrm{CH}_{3} \mathrm{CH}_{2}$ & $\mathrm{PhCH}_{2}$ & 1.09 \\
6 & $\mathrm{CH}_{3}\left(\mathrm{CH}_{2}\right)_{2}$ & $\mathrm{CH}_{3}$ & 1.10 \\
7 & $\mathrm{CH}_{3}\left(\mathrm{CH}_{2}\right)_{2}$ & $\mathrm{CH}_{3} \mathrm{CH}_{2}$ & 0.55 \\
8 & $\mathrm{CH}_{3}\left(\mathrm{CH}_{2}\right)_{2}$ & $\mathrm{PhCH}_{2}$ & 2.02 \\
9 & $\mathrm{PhCH}_{2}$ & $\mathrm{CH}_{3}$ & 1.72 \\
\hline
\end{tabular}

a) $\alpha$-amino acid, $4.4 \times 10^{-3} \mathrm{mmol} ; \alpha$-keto acid, $4.4 \times 10^{-3} \mathrm{mmol} ; \mathrm{Cu}^{2+}, 2.8 \times 10^{-3} \mathrm{mmol} ; \mathrm{ZrPL}^{-\mathrm{C}_{12}}$ (1), $25 \mathrm{mg}(\mathrm{PL}$ content $0.52 \mathrm{mmol} / \mathrm{g})$. reaction time, 7 days.

b) Analyzed by HPLC for Ala and calculated on the basis of initial reaction rates. Initial rate, $0.7 \times 10^{-4} \mathrm{mmol} / \mathrm{cm}^{3} \mathrm{~h}$.

$\mathrm{ZrPL}-\mathrm{C}_{12}(1) \sim \mathrm{ZrPL}-\mathrm{C}_{12}(6)$ の系に和ける, 粉体の $\mathrm{N} / \mathrm{C}$ と Ala 生成量との関係を示した。Ala 生成量は, N/C の減少につれて, ほぼ直線的に増加していること が分かる。以上の事実は, 疎水性の強い有機基が ZrP 層 間にインタカレーションされるほど層間の疎水性が強く なり，基質の取り达久に際して濃縮効果が現れ，その結 果, 反応性が増大したものと考光られる。

表-4 に, $\mathrm{ZrPL}-\mathrm{C}_{12}(1)$ を用いて, 種々の $\alpha-ア ミ ノ$ 酸と $\alpha$ ーケト酸間のアミノ基転移反応を行った結果を示 した。No.1〜5 および No.7〜9 を比べて見ると，ここ 
でも全体として $\alpha-$ ア ノ酸打よび $\alpha-$ ケ酸ともに, 䠅 水性の大きい系采ぞ反応性が高くなる傾向が認められ

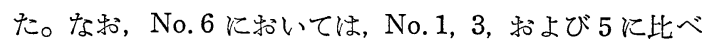
て蹯水性が大きいと考穴られるにもかかわらず，反応性 が低下した。これは，図-2 に拈ける $\mathrm{Cu}^{2+}$ イオンとのケ

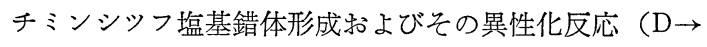
E) の速度が遅くなったためと考光られる。

以上, ビタミン $\mathrm{B}_{6}$ 補酵素であるピリドキサールを層 間に修飾した $\gamma$ リン酸ジルニニウムを合成し， $\alpha$-アミ ノ酸と $\alpha$-ケト酸とのアミノ基転移反応に応用したとこ ろ, 高い触媒活性を有していることが判明した。さら に，層間に鎖長の異なる有機基を同時に修飾した時，層 間の蹯水性が高くなるほぞ触媒活性が高くなることが判 明した。

\section{文献}

1) A. Clearfield, G. D. Smith : Inorg. Chem., 8, 431 (1969)

2) S. Yamanaka : Inorg. Chem., 15, 2811 (1976)

3) a) S. Yamanaka, M. Matunaga, H. Hattori : J. Inorg. Nucl. Chem., 43, 1343 (1981)

b) S. Yamanaka, M. Sarubo, K. Tadanobu, M. Hattori : Chem. Lett., 1255 (1991)

c ）山中昭二, 服部 信 : 触媒, 24, 25 (1982)

4) T. C. Bruice and S. J. Benkovic, "Bioorganic Mechanism”, Benjamin, New York, 1966, Vol. 2, p. 226

5) N. Kaneda, M. Sato, and K. Yagi : Anal. Biochem., 127, 49 (1982)

\title{
The Synthesis and Application of $\gamma$-Zirconium Phosphate Modified with Pyridoxal
}

\author{
Gyokugou $\mathrm{KAKU}^{*}$, Takayoshi FujII*, Seishiro ITo* \\ Masakuni Yoshinara* and Toshihisa Maeshima* \\ * Faculty of Science and Engineering, Kinki University, \\ Kowakae, Higashi-Osaka 577, Japan
}

\begin{abstract}
$\gamma$-Zironium phosphate $(\mathrm{ZrP})$ was allowed to react with pyridoxal-5'-phsophate (PL) and/or together with several organic phosphates bearing different chain lengths. The resulting powders were found to be intercalated by PL and/or organic phosphates in the layer of $\mathrm{ZrP}$ and the basal space increased with the increase of the chain length. Transamination between phenylalanine and pyruvic acid was carried out in the presence of the modified powders. The addition of $\mathrm{Cu}^{2+}$ ion accelerated the reaction and the highest yield was observed for the $\mathrm{ZrP}$ powder modified with $\mathrm{PL}$ and $n-\mathrm{C}_{12} \mathrm{H}_{25} \mathrm{OPO}_{3} \mathrm{H}_{2}$.
\end{abstract}

Key-words : $\gamma$-Zirconium phosphate, Pyridoxal, Transamination 